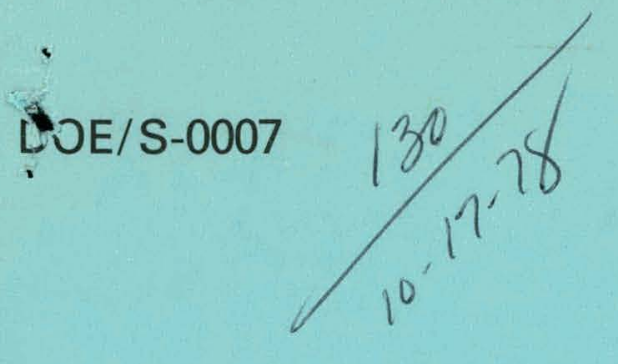

\title{
Equal Employment Opportunity Plan Development Guidance
}

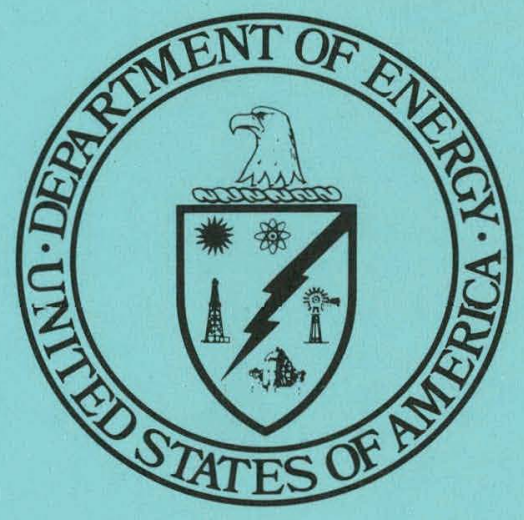

September 1978

\author{
U.S. Department of Energy \\ Office of the Secretary \\ Office of Equal Opportunity
}




\section{DISCLAIMER}

This report was prepared as an account of work sponsored by an agency of the United States Government. Neither the United States Government nor any agency Thereof, nor any of their employees, makes any warranty, express or implied, or assumes any legal liability or responsibility for the accuracy, completeness, or usefulness of any information, apparatus, product, or process disclosed, or represents that its use would not infringe privately owned rights. Reference herein to any specific commercial product, process, or service by trade name, trademark, manufacturer, or otherwise does not necessarily constitute or imply its endorsement, recommendation, or favoring by the United States Government or any agency thereof. The views and opinions of authors expressed herein do not necessarily state or reflect those of the United States Government or any agency thereof. 


\section{DISCLAIMER}

Portions of this document may be illegible in electronic image products. Images are produced from the best available original document. 
Available from:

National Technical Information Service (NTIS)

U.S. Department of Commerce

5285 Port Royal Road

Springfield, Virginia 22161

Price: Printed copy: $\$ 5.25$

Microfiche: $\quad \$ 3.00$ 


\section{Equal Employment Opportunity Plan Development Guidance}

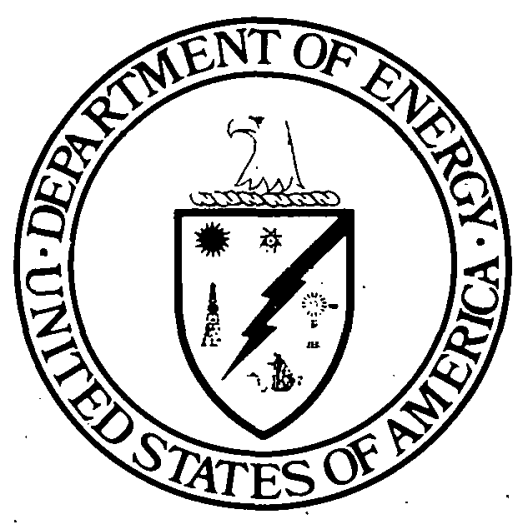

September 1978

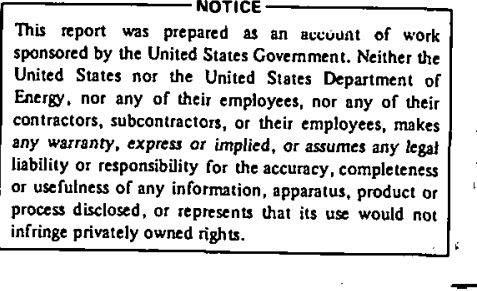

\section{U.S. Department of Energy}

Office of the Secretary

Office of Equal Opportunity 


\section{Department of Energy \\ Washington, D.C. 20545}

The purpose of this publication is to provide instructions for the development of EFO Plans for Fiscal Year 1979. It supplements the National EEO Plan for the Department of Energy issued in August 1978 (DOE/S-0002) .

The material included should be used immediately as guidance to develop, document, and implement subordinate echelon commitments to EFO. A schedule for the development and submission of EFO Plans is included.

Most of the continuing requirements will be published at a later date as part of the directives system. Any comments or helpful suggestions concerned with the program outlined would be appreciated by the office of Equal Opportunity.

$$
\begin{aligned}
& \text { Harim A. Sowdin } \\
& \text { Marion A. Bowden, Director } \\
& \text { Office of Equal Opportunity }
\end{aligned}
$$


I. EEO Plan Submission Schedule

II. Department of Energy EFO Plan Development Guidance 2

1. General

2. Legal Requirements of EEO Plans

2

3. Civil Service Commission Directives

4. National EEO Plan

$2-3$

5. Regional EFO Plans

$3-5$

6. Subordinate EEO Plans

7. Assessment Procedures

$6-8$

8. Reporting Requirements

Appendix I

- Organizations Required to Prepare Regional Plans

Appendix II - National Availability Materials

Appendix III - Reporting Requirements and Formats $16-21$

Illustration I - Sample Pre-Plan Development Assessment $22-25$

III. Section 717 of the Equal Employment Opportunity Act of 1972

IV. CSC Bulletin 713-50, Fiscal Year 1979 Equal Employment Opportunity Plans

V. FPM Letter 713-40, Equal Employment Opportunity Plans 
July 7

August 11

Sept. 29

oct. 2-31

Nov. $1-20$
Distributed preliminary National EEO Plan for the Department of Energy

Distributed National EFO Plan approved by Civil Service Commission

Distributed EFO plan development guidance

Each organization reviews all program areas of the Departmental Plan and determines the action items which it needs to implement. It assesses its own EEO situation and based upon these reviews sets forth in an EFO Plan its EFO commitments. These cammitments identify the problem, state what can be done to overcame it (in quantitiative terms, if applicable), who is going to do it, and when it will be done.

Each organization identified in Appendix I submits its EEO Plan to the Office of Equal Opportunity. Those expected to sulmit a plan to the CSC, also identified in Appendix I, submit the plan to the CSC at this time.

The Office of Equal Opportunity either approves the EFO Plan and notifies the organization to proceed to fulfill its commitments or will return the document to the organization for necessary adjustment. 
1. General. This publication is to provide guidance in the development and submission of EEO Plans. It requires affirmative action by all echelons within the Department of Energy. Affimative Action is defined as positive action designed to bring about meaningful change. Its purpose is to overcome the effects of past discrimination and to prevent the occurrence of employment discrimination. It consists of policies, practices and actions specifically designed to improve the opportunities for minorities and women, along with others, for employment, development, and advancement. The following programs and requirements are for the purpose of integrating equal employment opportunity considerations with the day-to-day personnel management activities of every manager and supervisor.

2. Legal Requirements of EEO Plans. The EEO Act of 1972 requires Federal agencies to submit national and reqional Equal Employmcnt oppurtunity plans to the Civil Service Commission annually, for approval. The law provides further that the plans submitted shall include, but not be limited to:

A. provisions for the establishment of training and education programs designed to provide a maximum opportunity for employees to advance so as to perform at their highest potential.

B. a description of the qualifications in terms of training and experience relating to equal employment opportunity for principal officials responsible for carrying out the EEO program.

C. the allocation of personnel and resources proposed to carry out the EEO program.

3. Civil Service Commission Directives. The instructions for development and submittal of EEO Plans contained in current CSC directives are applicable within the Department of Eriergy (See FPM Letter 713-40 and CSC Bulletin 713-50). Specific responsibilities and supplemental instructions are provided in the following paragraphs.

4. National EEO Plan. The Department of Energy National Plan is the EEO Plan issued by the Deputy Secretary. It identifies problems that exist on a Department-wide basis, specifies actions planned for their resolution during the time frame of the plan, assigns major responsibility for carrying out planned action, and establishes target dates for accomplishment. 
A. Development. The Director of Equal Employment Opportunity (Director, Office of Equal Opportunity) prepares the DOE plan, obtaining appropriate participation and coordination of planned actions and targets. The Director, Office of Personnel Management advises on and particpates in development of the National EEO Plan.

(1) Directors of Special Emphasis Programs (Federal Women's Program, Hispanic Employment Program, Upward Mbbility Program, develop action items based on their assessment of the EEO situation and incorporate the action items into the overall EEO Plan.

B. Approval. The DOE National EEO Plan is approved by the Office of Federal Equal Employment Opportunity, U. S. Civil Service Conmission.

C. Cormunication. The DOE Plan is responsive to the overall EEO situation and needs of the Department and contains actions required to be taken within subordinate organizations. It is sent to all responsible officials at the time of its submittal to the Civil Service cormission to provide a basis for preparation and submittal of Regional EEO plans as discussed below.

D. Revisions of the DOE EEO Plan. Following review by the Civil Service commission or at any time during the time frame of the plan, the DOE plan may be revised. Revisions will be developed, approved, and communicated as in the initial plan.

5. Regional EEO Plans. The EEO Act of 1972 requires Regional EEO Plans. A separate plan is required by each DOE organization identified in Appendix I. These plans are to be prepared by the EEO officer in cooperation with the Special Emphasis Program Managers, and representatives of the personnel staff in accordance with current CSC directives. The purpose of the regional plans is to encourage and provide information on specific affirmative actions based on local situations.

A. Regional Plans for Washington, D. C. The Federal Energy Regulatory Commission and the Headquarters Organization of DOE will prepare separate plans and submit them to the Director, Office of Equal Opportunity for approval. Both plans will be submitted to the Civil Service commission for review and approval.

B. Exclusion of Field Offices. Field organizations not included in Appendix I will prepared EFO commitments. These commitments should follow the modified plan development procedure given in current CSC directives. These plans will not be submitted to the regional offices of the CSC, but should be made available to those offices upon request. 
C. Development. Plans should be based on the identification of problem areas or impediments to equal employment opportunity in all organizations, occupations, and levels of responsibility.

D. Format and Content. Regional plans should be similar in format to the DOE EFO Plan. They should cover only those items where the assessment indicates that there is a local problem which coincides with the identified national problem. Also, items which provide for management and staffing of the EEO function should be included for implementation. The plans should include additional planned action based on the assessment of the local situation. All organizations listed in Appendix I, regardless of size, will prepare full EEO plans.

The actions 1ncluded under each program area will vary among offices and with local situations. It is not necessary to include an action which is not significant simply to account for it in the plan. A small number of specific planned actions in significant areas may comprise an effective plan for a given period, whereas comprehensive statements of general intent are inadequate as action plans. All plans must provide for coverage of the legal requirements in the EEO Act of 1972 and current CSC directives.

E. Goals. The long-range goals of the regional EEO plans should directly or indirectly incorporate long-range goals of the Department EEO Plan which are common goals but may include additional goals based on local situations. The immediate goals of the regional plans should reflect the local situation and potential but should be generally consistent with the goals of the Department plan. They should be specific and expressed in terms which permit achievement to be evident from employment data. They should be ambitious in meeting problems but realistic in view of the potential in the period covered.

F. Action Items. Specific planned actions whioh are responsive to the problem identified in the assessment, should be clearly stated along with the organization or person responsible for each action. The actions should be directed at existing problems in assuring equal employment opportunity.. Actions called for in special emphasis programs, such as the Federal Women's Program, the Hispanic Employment Program, and the Upwand Mobility Program should be considered in view of the local situation. All planned actions should be consistent with DOE personnel management policies and procedures: 
G. Target Dates. Wherever practical, target dates should be established for actions which have identifiable stages of completion. The frequency or extent of an action may be suitable as a target when the action is of a "continuing" or "as needed" nature.

H. Consultation. In the development of EFO objectives and goals, there should be consultation with minority groups, comminity leaders, labor organizations, employees, women's groups, and other interested parties and suggestions received from those sources considered in setting commitments.

I. Submittal of Regional EEO Plans. All regional plans will be sutmitted to the Director of Equal Employment Opportunity for review, comment, and approval. Plans should be received ninety days after receipt of the National EFO Plan for the Department of Energy. All plans should be ready for implementation at the start of the fiscal year. Organizations of 1,000 or more employees required to sulmit plans to the CSC should do so at the same time the plan is forwarded to the Office of Equal Opportunity.

J. Revision of Regional EPO Plans. Following review and approval by the Director of Equal Employment Opportunity, and by the Civil Service commission, or at any time during the life of the plan, revision may be required or warranted. Revisions should be developed and submitted as in the initial regional plan.

K. Canmunication of Regional EEO Plans. The regional plan is responsive to the local situation and contains actions to be taken by different officials within the onganization. It is sent to all responsibile officials; as well as to advisory cormittees and employees with special EBO responsibilities. Presentation and discussion of the EFO plan and related plans for personnel management among officials and supervisors at staff meeting is a suggested step in communicating the plan.

6. Subordinate EEO Plans. EFO cormitments of offices within or. serviced by Field organizations, and individual Assistant Secretaries and other offices at headquarters, may be required to submit commitments. The commitments of these organizations contribute to regional plans and reflect commitment to and participation in affirmative actions. Subordinate cormitments are prepared in accordance with instructions from the officials requiring them. Such officials will determine the form and content of the commitments and the schedules for submittal. 
7. Assessment Procedures. An accurate and comprehensive assessment of the organization's EEO situation is the first step in the development of an effective EEO affirmative action program. Such an assessment includes an analyses of factual data and the identification of major EEO problems.

A. Purpose. The purposes of the assessment are:

(1) to address any objectives which were unattained and action items still in process or unresolved from the previous plans.

(2) . to provide clear and comprehensive narrative assessment sumaries of the current stati1a of inafor EDO program areas;

(3) to identify any curcent conditions which impede full realization of EEO goals;

(4) to identify (through concise problem statements) those EEO problems which require priority attention and solution basod upin the conditions identified as a result of (1), (2), and (3) above.

B. Self-assessment guide. A self-assessment guide is contained in FPM Letter 713-40. The criteria listed in the guide are intended to serve as a starting point for the assessment process and may well suggest other factors to be considered. Specifically responding to the questions listed is not necessary since many of the responses may not be meaningful with respect to the overall assessment or will not relate to any of the priority problems identified, and therefore, will merely add to the length of the plan. A workforce analysis technique, which may be used in pre-plan development, is described in Illustration $I$.

C. Evaluations of personnel and equal employment opportunity conducted by the Department, the csc or other Federal or private organizations should be used in the assessment process.

D. Recruitment and Placement Goals. Each organization must evaluate its own unique EEO situation and, as a result of the evaluation, establish employment goals and the timetable for accomplishment. Individual organization goals may be the same as the national goals or they may be higher or lower as the organization EEO profile indicates as necessary. See paragraphs 4 and 5 above. 
(1) Realistic Base. All EEO goals must be developed and structured around pertinent and quantificable data and information which contributes to the assessment of the program and the attainment of EFO objectives. Cormitments and goals must be established on a realistic basis, taking into account available opportunities within the organization, estimated turnover, anticipated hiring and occupational needs. These factors should be related to the potential supply of women and minority group persons from the workforce and in the recruiting area who are qualified or who can reasonably be expected to qualify after appropriate training and development.

(2) Reasonable Representation. Any numerical recruitment and placement goals which are established must relate and apply as closely as possible to the organizational, grade level or occupational areas which are below what reasonably could be expected within the availability of candidates. In the CSC system which is uniformly applied to several departments and agencies, there are fewer opportunities for improvisation in the conduct of a recruitment and examination program. When establishing goals for professional hires consider the presence of minorities and women in each particular academic disciple and in currently graduating classes, availability within the Federal workforce and on CSC registers. The recruitment area customarily used as a source for general recruitment for each occupation or grade level should be used as the base reference. It may be the immodiate commuting area, the standard metropolitan area, a section of the country or the entire country.

The ability to staff vacancies through upward mobility programs also must, be considered. Limited national availability materials are given in Appendix II. Appropriate offices of the CSC and the Department of Labor can supply more definitive local information.

(3) Presentation. Numerical recruitment and placement goals should be presented with reference to the total number of anticipated opportunities for taking affirmative action. Furthermore, goals should be established by sex and individual minority group when the assessment indicates that a particular group is underrepresented. 
(4) Merit System: Affirmative action to attain numerical recruitment and placement goals must be carried out within the context of the merit system. Affimative action can be accomplished within the merit system, although it may involve exploring and using alternative staffing options.

(5) Exceptions. Regional plans which apply to organizations of. 75 or less should include specific planned actions which are designed to achieve, within the merit system, the numerical goals established, rather than include the numercial goals themselves. The goals should be submitted for review and approval with the EFO plan.

8. Reporting Requirements. A continual critical review of the progress made against the commitments outlined in the Plan is essential.

A. Purpose

(1) measure progress in the employment and utilization of women and minorities;

(2) determine patterns of selection of women and minorities, identify the causes of non-selection and take positive steps towand effecting change;

(3) identify and analyze problem areas and initiate projects or program changes; and,

(4) revise EEO commitments.

B. Types. A brief description of each report is provided below. Instructions for the completion of the statistical reports is given in Appendix III.

(1) Annual Accomplishment Reports

(a) National. In accordance with the EFo Act of 1972 and Civil Service Commission requirements, the National EFO Plan for the Department of Energy sulmitted to the Canmission for approval, includes a report of accomplishment of the action items included in the previous plan. The Director, Office of Equal Opportunity prepares the report using information from automated records, quarterly narrative and statistical reports, and personnel management and EEO evaluations. Achievements or the extent of achievements, together with problems encountered, are summarized as the basis of the 
report. Action items which are significant are discussed in terms of their contribution to achievement of the goals. The Director, Office of Personnel Management advises on and participates in preparation of the accomplishment report and concurs in each report prior to referral to the Deputy Secretary.

(b) Regional. A separate accomplishment report must be submitted with the EEO Plan by each office required to prepare a regional plan. It is to be submitted to the Director, Office of Equal Opportunity and the appropriate CSC office, when CSC plan approval is required (See Appendix I). A summary of achievement of the previous plan provides the basis for reporting accomplishment of separate action items. Each action item in the previous EEO plan should be considered; however, it is not necessary to discuss an item merely to account for it in the report. The significant action items should be discussed in terms of achievement or nonachievement of the goals and in statistical terms whenever possible.

(2) Report on National EEO Plan and Action Coordination and Tracking System (ACIS) Report

Each organizational unit of the Headquarters office, the Federal Energy Regulatory Commission, and the offices listed in Appendix I shall report on a quarterly basis the progress made toward achieving the Department's goals to increase overall minority representation and to increase the utilization of women in positions GS-9 and above.

(3) Quarterly Narrative Reports. Each office required to prepare a regional EEO plan will submit on a quarterly basis a narrative report signed by the head of the organization, to the Director, office of Equal opportunity. The report should include significant progress made under the organization's EEO programs, problems encountered in program irmplementation, and projects undertaken to enlarge job opportunities for wamen and minority group members.

(a) The report should indicate the total number of lateral reassignments into the organization and the number of women and members of minority groups since this data will not be provided by the statistical summaries.

(b) Noteworthy accomplishments, breakthrough appointments, or any other material which could be shared with others should be submitted in the form of articles ready for publication within the Department or by the CSC in its EFC publications. When possible photographs should be included. 
(4) Quarterly Accession, Promotion and Current Staffing Reports. Each office required to prepare a regional EFO plan will submit statistical data on accessions, promotions, and current staffing with its narrative report. Once the data maintained in the Personnel Automated Records and Information System (PARIS) has been validated, the statistical summaries will be discontinued. 


\section{ORGANIZATIONS REQUIRED TO PREPARE REGIONAL PLANS}

Plan Approval Required by Office of Equal Opportunity

Region I, Boston

Region II, New York

Region III, Philadelphia

Regiun IV, Atlanta

Region V, Chicago

Region VI, Dallas

Region VII, Kansas City

Region VIII, Denver

Region IX, San Francisco

Region $\mathrm{X}$, Seattle

Chicago Operations Office

Idaho Operations Office

Oak Ridge Operations Office

Richland Operations Office

(Includes Fast Flux Project Office)

San Francisco Operations office

Savannah River Operations Office

Nevada Operations Office

Albuquerque Operations Office

Alaska Power Administration

Southeastern Power Administration

Southwestern Power Administration

Bonneville Power Administration

Western Area Power Administration

Bartlesville Energy Technology Center

Grand Forks Energy T'echnology Center

Laramie Energy Technology Center

Morgantown Energy Technology Center

Pittsburgh Energy Techology Center

Environmental Measurement Laboratory, New Yori

Uranium Resource Facility, Grand Junction

Clinch River Project Office

Pittsburgh Naval Reactors Office

Schnectady Naval Reactors Office

Naval Petroleum Reserve, Elk Hill

Technical Infonmation Center, Oak Ridge

Headquarters

Federal Energy Regulatory Commission
Plan Approval Required by Appropriate CSC Office
Dallas

Seattle

Denver 
MINORITY/SEX DISTRIBUTION BY WHITE-COLLAR OCCUPATION

ALL-AGENCY SUMAARY: FULI-TIME PERMANENT

FEDERAL GOVERNMENT EMPLOYEES

$$
11 / 30 / 76
$$

Occupation Group Title, Code and Number of Employees

Miscellaneous Occupat1ons $1-99(48,238)$

Soclal Science-Psyc. Welfare $100 \quad(51,285)$

Personnel-Management $200 \quad(43,369)$

General Adminlocrative $300 \quad(455,520)$

Blological Sciences $400 \quad(41,271)$

Accounting and Budget $500 \quad(118,707)$

Medical and Health Sciences $600 \quad(115,732)$

Veterinary Medical Sciences $700 \quad(3,055)$

Englneering and Archltecture $800 \quad(148,504)$

Legal and Related Occupartons $900 \quad(63,104)$

Informat1on and Arts $1000(20,023)$

Business and Industry $1100(67,835)$ $1200 \quad(1,342)$

Physical Sclences $1300 \quad(40,901)$

Library Science and Archives $1400 \quad(7,384)$

Mathemat10o-Stetislics $1500(14,238)$

Equipment Fac1lities $1600(13,591)$

Education $1700 \quad(27,886)$

Invest 1gation $1800 \quad(45,683)$

Commodity Qual1ty Control $1900(18,433)$

Supply $2000 \quad(58,479)$

Trapsportation $2200 \quad(42,719)$

Postal Service $2300 \quad(464,030)$

Students 3500 (590)

AMERICAN

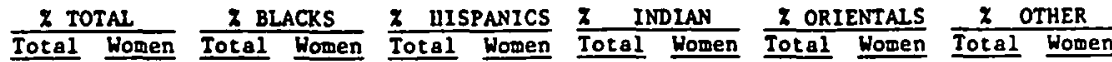

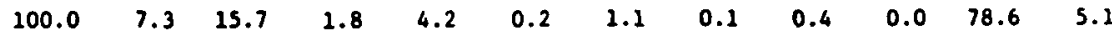

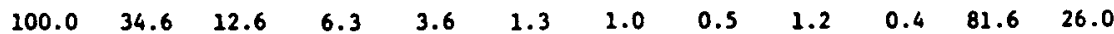

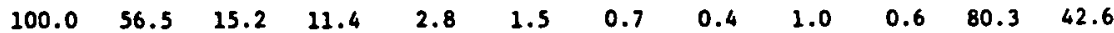
$\begin{array}{llllllllllll}100.0 & 68.3 & 17.1 & 13.2 & 2.7 & 1.8 & 1.1 & 0.8 & 0.9 & 0.6 & 78.2 & 51.9\end{array}$ $\begin{array}{llllllllllll}100.0 & 9.0 & 4.8 & 1.1 & 1.7 & 0.1 & 1.4 & 0.0 & 0.7 & 0.2 & 91.4 & 7.6\end{array}$ $\begin{array}{llllllllllll}200.0 & 48.4 & 12.5 & 9.2 & 2.5 & 1.2 & 0.5 & 0.3 & 1.7 & 0.6 & 82.8 & 37.2\end{array}$

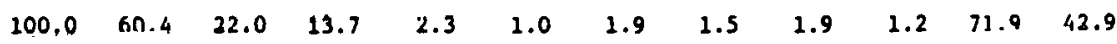
$\begin{array}{llllllllllll}100.0 & 2.4 & 3.1 & 0.1 & 3.0 & 0.1 & 0.2 & 0.0 & 2.8 & 0.2 & 91.0 & 2.0\end{array}$

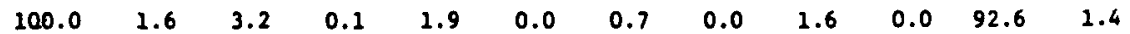

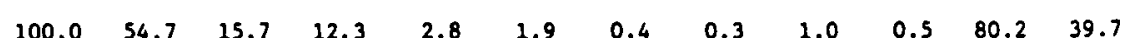

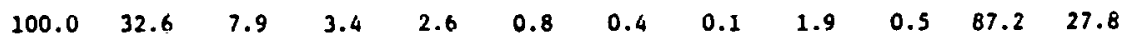
$\begin{array}{llllllllllll}100.0 & 29.2 & 8.5 & 4.7 & 2.7 & 0.7 & 0.8 & 0.3 & 0.8 & 0.3 & 87.2 & 23.1\end{array}$ $\begin{array}{llllllllllll}100.0 & 4.5 & 7.8 & 1.6 & 0.9 & 0.0 & 0.0 & 0.0 & 1.4 & 0.1 & 89.9 & 2.7\end{array}$

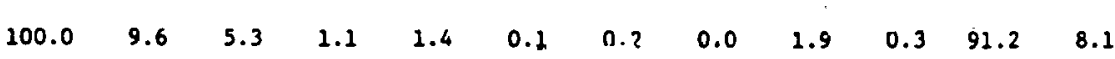
$\begin{array}{llllllllllll}100.0 & 66.0 & 18.4 & 11.7 & 1.3 & 0.8 & 0.3 & 0.2 & 1.3 & 1.0 & 78.6 & 52.3\end{array}$ $\begin{array}{llllllllllll}100.0 & 34.5 & 14.0 & 9.5 & 1.4 & 0.4 & 0.1 & 0.1 & 1.7 & 0.4 & 82.8 & 24.1\end{array}$ $\begin{array}{llllllllllll}100.0 & 2.8 & 5.2 & 0.6 & 2.2 & 0.0 & 0.4 & 0.0 & 0.8 & 0.0 & 91.4 & 2.2\end{array}$ $\begin{array}{llllllllllll}100.0 & 40.8 & 5.4 & 2.5 & 1.5 & 0.5 & 14.9 & 9.8 & 1.2 & 0.4 & 77.1 & 27.6\end{array}$ $\begin{array}{llllllllllll}100.0 & 6.5 & 4.7 & 1.0 & 3.5 & 0.3 & 0.4 & 0.0 & 0.6 & 0.1 & 90.8 & 5.1\end{array}$ $\begin{array}{llllllllllll}100.0 & 3.5 & 4.4 & 0.3 & 2.6 & 0.1 & 0.3 & 0.0 & 0.9 & 0.0 & 91.8 & 3.1\end{array}$ $\begin{array}{llllllllllll}100.0 & 44.0 & 15.0 & 8.3 & 4.0 & 1.3 & 0.7 & 0.2 & 0.9 & 0.4 & 79.4 & 33.8\end{array}$

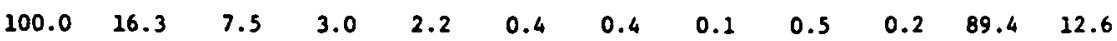

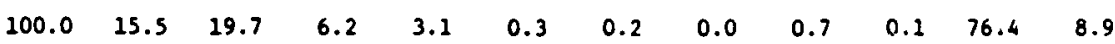
$\begin{array}{llllllllllll}100.0 & 67.5 & 44.6 & 30.5 & 9.7 & 6.8 & 1.0 & 0.7 & 1.2 & 0.7 & 43.6 & 28.8\end{array}$ 
U.S. CIVIL SERVICE COMISSION

EQUAL EMPLOYMENT OPPORTUNITY PROGRESS REPORT

AS OF NOVEMBER 1977

FULL-TIME PERMANENT EMPLOMENT NOV 77

$\frac{\text { GOVT-WIDE TOTAL (NON-POSTAL) }}{\text { NUMBER }}$

TOTAL

WOMEN

BLACK

HISPANIC

NATIVE AMERICAN

ORIENTAI

$\begin{array}{rr}1,774,447 & 100.0 \\ 614,627 & 34.6 \\ 264,627 & 14.9 \\ 64,211 & 3.6 \\ 20,534 & 1.2 \\ 19,220 & 1.1\end{array}$

DISTRIBUTION OF WOMEN AND MINORITIES
FEDERAL FULL-TIME

PERMANENT EMPLOYMENT

November 30,1977

WOMEN

$35 \%$

BLACK

$15 \%$

HISPANIC

$4 \%$

$2 \%$ ORIENTAI \& ALI

OTHER

REPRESENTATION BY GRADE LEVEL
GS $9 .-12$

$(\$ 6,219-\$ 17,757) \quad(\$ 15,090-\$ 28,444)$

68.2

25.8

22.5

12.2

GS 13-15

November 1976

\% Women

5.5

6.4

\% Minority

5.9

6.7
GS $13-15$

$(\$ 26,022-\$ 47,025) \quad(\$ 42,423-\$ 47,500)$

5.9

3.2

6.7

4.9
ENERGY NQHBER

PERCENT

16,332

4,983

1,066

613

121

191

100.0

30.5

6.5

3.8

0.7

1.2
1977 Annual Average

$41 \%$ ( $36 \%$ of full-time)

$9 \%$

$4 \%$

$2 \%$ 
Total representation of women and minorities is as follows:

\begin{tabular}{|c|c|c|c|}
\hline & Energy & $\begin{array}{l}\text { Federal Full-Time } \\
\text { Permanent Employment } \\
\text { Average, Nov. } 30,1977\end{array}$ & $\begin{array}{l}\text { National Non-Farm } \\
\text { Labor Force Employment } \\
1977 \text { Annual Average }\end{array}$ \\
\hline $\begin{array}{l}\text { Homen } \\
\text { ifinority }\end{array}$ & $\begin{array}{l}30.5 \% \\
12.2 \%\end{array}$ & $\begin{array}{l}34.6 \% \\
20.8 \%\end{array}$ & $\begin{array}{l}41.2 \% \\
15.2 \%\end{array}$ \\
\hline
\end{tabular}

REPRESENTATION BY GRADE LEVEL

As Indicated in tive report to the President, we believe the level of jobs held by women ans afnorities to je a better measure of their advancement (and therefore of the effectiveness of affirmative action efforts) than overall represontation. For your agency, these representation levels are as follows:

Distribution of Women and Minorities
by General Schedule Grade
Full Time Permanent Fmplaymont Nơ. 30, $19 \% 1$
GENERAL SCHEDULE \& EQUIVALENT
Energy
Government
Average

$\begin{array}{lll}\text { GS 1-8 } & 72.6 & 68.2 \\ \% \text { Women } & 22.1 & 23.8 \\ \% \text { Minority } & & \\ \text { GS 9-12 } & 23.6 & 22.5 \\ \% \text { Women } & 10.1 & 12.2 \\ \% \text { Minority } & & \\ \text { GS 13-15 } & 6.1 & 5.9 \\ \text { \% Women } & 5.6 & 6.7 \\ \% \text { Minority } & & \\ \text { GS 16-18 } & & 3.2 \\ \text { \% Women } & 1.1 & 4.9 \\ \text { \% Minority } & 3.4 & \end{array}$

Over the past ycar, the following changes took place:

Grade by Grade Representation-Net Change in Peitunrage Nov. 30, 1976-Nov. 30, 1977

GENERAL SCHEDULE \& EQUIVALENT

$\underline{\text { Energy }}$

Government Average Change from 1976.

GS $1-8$

Womer

Minorities

NA

$+0.5$

NA +0.5

GS $9-12$

Women

Minorities

NA

$+1.2$

NA

$+0.5$

GS $13-15$

Women

Minorities

NA

$+0.4$

NA

$+0.3$

GS $16-18$

Women

Minorities

NA

$+0.4$

NA

$+0.2$

(Extract)

U.S. Civill Service Commission Memo Employment of Women and Minorities in the Federal Service - Special Report April 7, 1978 and Apri1 28, 1978. 
National Avallability of Women and Minorities for Positions in Officials \& Managers, and Professional Employment Categories

\begin{tabular}{|c|c|c|c|c|c|c|}
\hline \multicolumn{7}{|c|}{$\begin{array}{l}\text { Women \& Minority Availability Conclusions } \\
\text { for Consideration in Preparing EEO Plans } \\
\text { (FY 78-79) }\end{array}$} \\
\hline & $\%$ & $\begin{array}{c}\% \\
\text { Total } \\
\text { Minority }\end{array}$ & $\begin{array}{l}\% \\
\text { Blacks }\end{array}$ & $\begin{array}{l}\% \\
\text { Spanish } \\
\text { Origin }\end{array}$ & $\begin{array}{c}\mathbf{Z} \\
\text { Asian } \\
\text { American }\end{array}$ & $\begin{array}{l}\% \\
\text { American } \\
\text { Indians }\end{array}$ \\
\hline Engineers & 1.85 & 4.75 & 1.45 & 1.63 & 1.58 & 0.09 \\
\hline Chemical Engineering & 1.80 & 3.83 & 0.82 & 1.24 & 1.62 & 0.15 \\
\hline Civil Engineering & 1.54 & 5.92 & 2,49 & 1.97 & 2.24 & 0.22 \\
\hline Electrical Engineering & 1.69 & 5.39 & 1.76 & 1.48 & 2.08 & 0.07 \\
\hline Mechanical Engineering & 1.00 & 4.22 & 1.37 & 1.30 & 1.49 & 0.06 \\
\hline Metallurgical Engineering & 1.06 & 2.83 & 0.92 & 1.12 & 0.79 & - \\
\hline Mathematics & 39.35 & 9.74 & 5.62 & 1.61 & 2.24 & 0.27 \\
\hline Chemistry & 15.55 & 9.85 & 4.01 & 2.21 & 3.45 & 0.18 \\
\hline Biology & 32.33 & 17.27 & 7.83 & 2.80 & 6.24 & 0.40 \\
\hline Physics & 6.31 & 5.78 & 1.63 & 1.43 & 2.65 & 0.07 \\
\hline Accounting & 25.22 & 11.05 & 4.82 & 3.73 & 2.32 & 0.18 \\
\hline Computing & 20.62 & 8.12 & 4.62 & 1.81 & 1.59 & 0.10 \\
\hline Nurs1ng & 98.63 & 14.03 & 9.93 & 2.38 & 1.46 & 0.26 \\
\hline Physicians & 11.01 & 18.46 & 4.46 & 7.18 & 6.70 & 0.12 \\
\hline Economics & 12.38 & 5.35 & 2.59 & 1.84 & .78 & 0.14 \\
\hline Library Sclence & 82.83 & 10.37 & 7.30 & 1.60 & 1.31 & 0.16 \\
\hline Legal & 8.46 & 7.82 & 4.14 & 2.92 & .58 & 0.18 \\
\hline Personnel & 41.00 & 16.11 & 10.00 & 4.51 & 1.24 & 0.36 \\
\hline Procurement & 41.00 & 16.11 & 10.00 & 4.51 & 1.24 & 0.36 \\
\hline
\end{tabular}

Ref: P/KA Research, Inc., report to ERDA (May 1976) 
APPENDIX III

Reporting Requirements for EEO

\begin{tabular}{|c|c|c|c|c|c|}
\hline Frequency & Activity & Subject & Report to & Due & Remarks \\
\hline 1. Annual & OEO & $\begin{array}{l}\text { Accomplishment of } \\
\text { EEO Objectives }\end{array}$ & $\begin{array}{l}\text { CSC } \\
\text { office of } \\
\text { Federal EDO }\end{array}$ & $\begin{array}{l}\text { With submission of } \\
\text {.National EEO Plan } \\
\text {. }\end{array}$ & $\begin{array}{l}\text { See instructions } \\
\text { given in section on } \\
\text { reporting require- } \\
\text { ments. }\end{array}$ \\
\hline 2. Annual & $\begin{array}{l}\text { Organizations } \\
\text { listed in } \\
\text { Appendix I }\end{array}$ & $\begin{array}{l}\text { Accomplishment of } \\
\text { EEO Objectives }\end{array}$ & Director, OEO & $\begin{array}{l}\text { With submission of } \\
\text { Fegional EEO Flan. } \\
+\end{array}$ & $\begin{array}{l}\text { See instructions } \\
\text { given in section on } \\
\text { reporting require- } \\
\text { ments. }\end{array}$ \\
\hline 3. Quarterly & $\begin{array}{l}\text { Hdqtrs: } \\
\text { FERC } \\
\text { Organizations } \\
\text { listed in } \\
\text { Appendix I }\end{array}$ & $\begin{array}{l}\text { FIP Hires All } \\
\text { Levels and GS-9 } \\
\text { and above }\end{array}$ & Director, OEO & $\begin{array}{l}\text { lst week after end } \\
\text { of FY quarter. }\end{array}$ & $\begin{array}{l}\text { See instructions } \\
\text { given in this } \\
\text { Appendix and section } \\
\text { on reporting } \\
\text { requirements }\end{array}$ \\
\hline 4. Quarterly & $\begin{array}{l}\text { Organizations } \\
\text { listed in } \\
\text { Appendix I }\end{array}$ & $\begin{array}{l}\text { Narrative Report: } \\
\text { Statistical Summaries } \\
\text { (1) FTP Hires } \\
\text { (2) Pramotions } \\
\text { (3) Current Staffing }\end{array}$ & Director, OEO & $\begin{array}{l}\text { 10th of month } \\
\text { following the end } \\
\text { of quarter } \\
\text { (orig. \& } 1 \text { copy! }\end{array}$ & $\begin{array}{l}\text { See instructions } \\
\text { given in this } \\
\text { Appendix and section } \\
\text { on reporting } \\
\text { requirements. }\end{array}$ \\
\hline
\end{tabular}


ORGANIZATION

FISCAL QUARIER

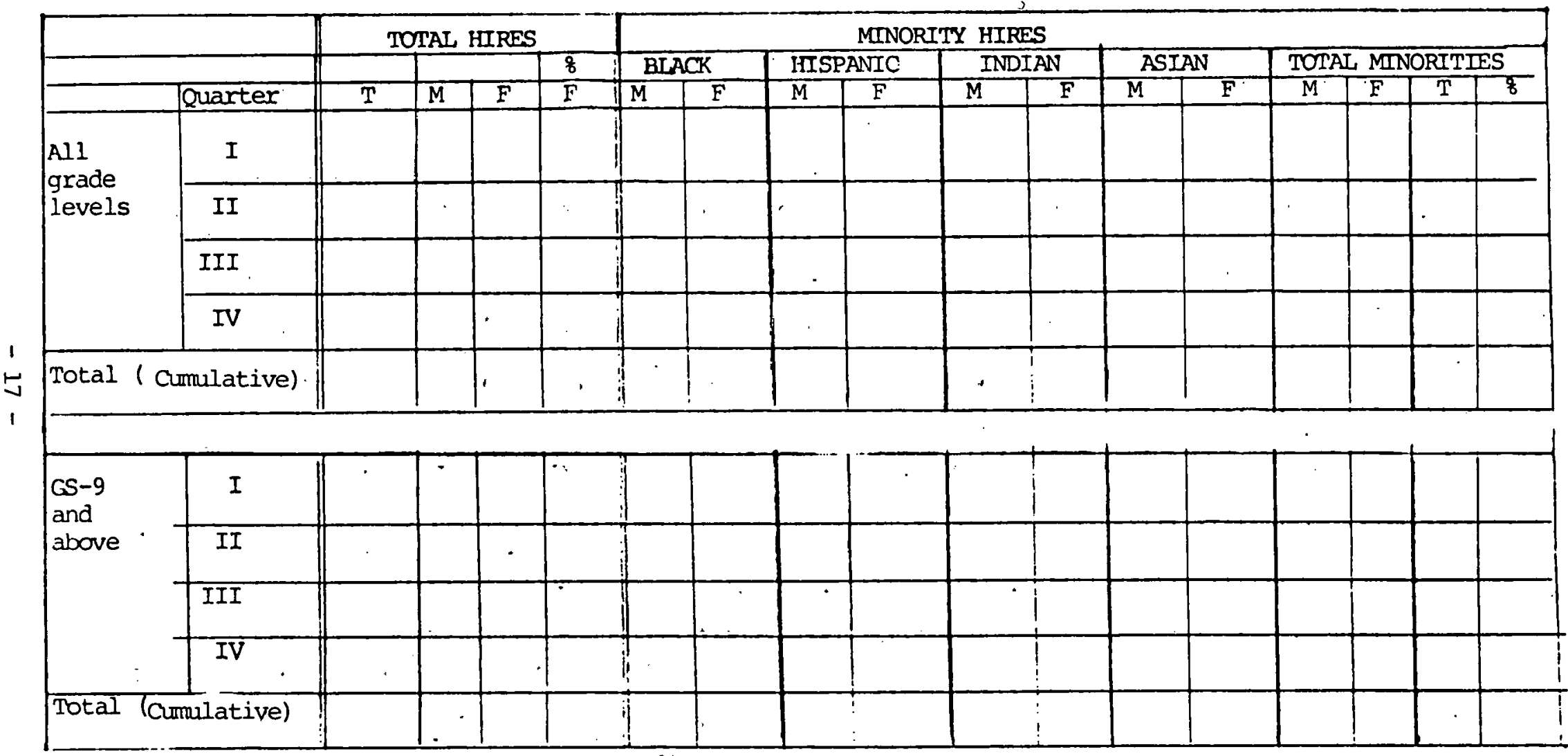

Fiscal Quarter

$$
\begin{array}{r}
\text { I - } 1 \text { Oct. }-31 \text { Dec. } \\
\text { II - } 1 \text { Jan. }-31 \text { Mar. } \\
\text { III - } 1 \text { Apr. }-30 \text { June } \\
\text { IV - } 1 \text { July-30 Sept. }
\end{array}
$$

Remarks

(1) Total Cumulative Reflect activity of earlier quarters as well as last quarter submission. 
Reporting Organization: Headquarters; Federal Energy Regulatory Commission All field offices listed in Appendix I

General Instructions: DOE National EEO Plan and Office of Equal Cpportunity Memorandum of July 31, 1978

1. Each organizational unit will report on a quarterly basis the progress made toward achieving the Department's goals to increase overall minority representation and to increase women in positions GS-9 and above.

2. Reports will consist of: the total full-time permanent hires during the last fiscal quarter and the number. and proportion who were minorities; the total number of hires GS-9 and above, and the number and proportion of women and minorities. The numbers to be reported should reflect (1) full-time permanent hires into DOE; (2) transfers into DOE from other government agencies; (3) reinstatements; and (4) conversions from other than full-time permanent to full-time permanent. Information concerning promotions, reassignments (including from field to Headquarters and between separate organizational entities at headquarters), and hires of other than full-time permanent should not be included on this report. The date FTP hire is placed on DOE payroll will determine the proper quarter for reporting. Quarterly reports are due in the Office of Equal opportunity one, week after the end of each fiscal quarter. Each major organizational unit at Headquarters reports quarterly progress at the first ACTS meeting scheduled in the. month following the end of the fiscal quarter. 
EEO Progress Report Quarterly

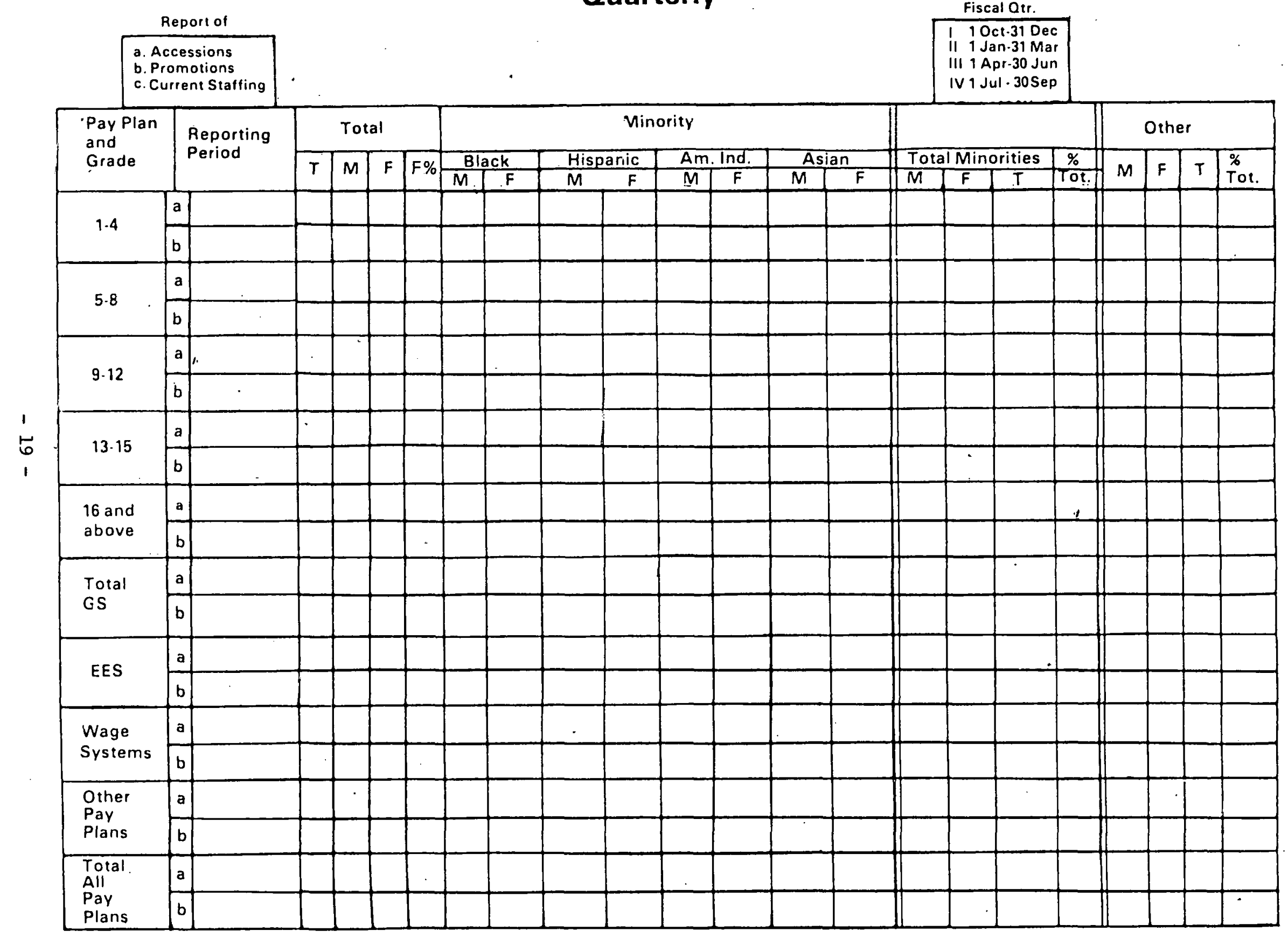


Reporting Organization: Each organization listed in Appendix I.

General Instructions: Section on Report Requirements and information provided below.

1. Each report shall consist of a brief narrative summary which describes the operation of the EEO Plan. Reports are to reach the Office of Equal Opportunity by the 10th of the nonth following the end of the quarter.

2. Statistical Reports. The form provided in this Appendix will be used in reporting the following: (1) Full-time permanent accessions; (2) Promotions; and (3) Current staffing at the close of the fiscal quarter. A separate copy of the form will be used to report each of the above.

\section{a. Full-Time Permanent Accessions:}

(1) Full-time permanent hires into DOE; (2) trañsfers into DOE from other government agencies;

(3) reinstatements; and (4) conversions from other than full-time permanent to full-time permanent. Information concerning promotions, reassignments (including from field to Headquarters and between separate organizational entities at headquarters), and hires of other than full-time permanent should not be included on this report. The date FTP hire is placed on DOE payroll will determine the proper quarter for reporting.

\section{b. Promotion:}

The quarterly promotion report is a count of the number of promotions into each grade; and the definition of "pramotion" for tris purpose is any action (irrespective of action code) which changes an employee's position and advances the employee to a higher grade and/or which increases the employee's salary.

c. Current Staffing:

Report the current staffing at the end of the fiscal quarter, using the last day of the quarter for reporting. 


\section{Quarterly EEO Progréss Reports \\ (continued)}

Reporting Organization: Each organization listed in Appendix I. .

General Instructions: Section on Report Requirements and information provided below.

d. Use of Format:

(1) Line a) - Report data for current quarter. Use separate form to report accessions, promotions, and current staffing.

(2) Line b) - Report cumulative totals. Use separate form to report accessions, promotions, and current staffing.

(3) Fiscal Quarters are:

$$
\begin{aligned}
& \text { I - } 1 \text { Oct. - } 31 \text { Dec. } \\
& \text { II - } 1 \text { Jan. - } 31 \text { Mar. } \\
& \text { III - } 1 \text { April - } 30 \text { June } \\
& \text { IV - } 1 \text { July - } 30 \text { Sept. }
\end{aligned}
$$

Note: Complete forms in detail and include all percentages at each grade-level group and totals. Complete percentage for Total Minorities. - 
PRE-PLAN-DEVELOPMENT ASSESSMENT

WORKFORCE ANALYSIS

The analytic technique described in this appendix is one acceptable method of determining the representativeness of the workforce: The analysis will help you to determine how the organization's occupations compare to government-wide employment in the same occupations and whether all organizations are open to minorities and women.

Ideally, we should be able to compare occupations in the Federal workforce with occupations in the civilian labor force. However, occupational classifications used by the Censue Bureau, Lhe Department of Labor, and the Federal government for its civilian and military employees are not directly comparable. Under the leadership of the Office of Management and Budget, work is currently proceeding to develop a Standard Occupational Classification system which could permit direct comparisons of occupations between the Federal and civilian labor forces. Until this work is completed, we will have to use analytic techniques which are not quite as precise as we would like.

The analysis presented here describes a simple method by which you can compare the composition of your organization's workforce with that of the government as a whole. The first question to answer for each distinct occupation analyzed is, which workforce should be used as the base of reference, the national Federal workforce, or the local Fcderal workforce?

The cholce between the 1 ocal or national Federal worktorce is determined by the normal recruiting area for the occupation and grade level being analyzed. If the recruiting area for the occupation being analyzed is a local area or state, then local or state-wide Federal workforce statistics should be used as the base of reference. If the recruiting area is nationwide, then national figures should be used. Current national base reference workforce figures are provided. Local base reference figures are available to you by the appropriate U. S. Civil Service Commission Regional office.

Following selection of the base reference workforce, the second step is to identify the percentage of minorities and non-minorities, by sex, in the base reference workforce for occupations comparable to those existing in the organization.

The next step is to identify the central tendency for each comparable occupation. The central tendency or representative employment range is administratively defined as the percentage of minorities and non-minorities, by sex, plus or minus 25 percentage, employed in each of the comparable occupations in the base reference workforce. 
An example may help here. If the percentage of Black males in the base reference workforce in the occupation being analyzed is 10 percent, then 25 percent of that percentage is 2.5 percent. The representative employment range for Black males is therfore between 7.5 percent and 12.5 percent for that specific occupation.

Now compare the percentage of minority and non-minority groups, by sex, in each occupation with the central tendency or representative ranges previously computed for the same occupation in the base workforce. This step will identify potential problem areas in specific occupations which must be investigated to explain why the occupation is not within the representative range of the base reference workforce. Occupations having less than 25 employees should not be analyzed.

This analysis is not to be submitted as part of the assessment report, but it must be available for review if requested. You are to report the output of this last step in the enclosed format. If all occupations analyzed are within the representative range by minority and majority group, by sex, nothing needs to be reported.

It is important to point out here that this analysis does not constitute a mathematical definition of equal employment opportunity. It is a simple analytic technique designed to isolate those occupations in which the probability of barriers to equal opportunity could reasonably be expected to be highest. Conversely, it arbitrarily excludes from consideration those occupations in which a minimum probability of barriers to equal opportunity could reasonably be expected to exist.

It would be a mistake to conclude that an occupation in the table automatically indicates that there is an EEO problem or discrimination. It does not. What it indicates is the possibility of an EEO problem. It is your job to explore the reasons behind the tendency and to determine whether or not there is a problem requiring affirmative action.

For example, the examination as to why a particular group is tabulated in a specific occupation may reveal a pattern of relative difference over a long time span, but it may also revea that for the past three years the accession rate of that group has been within or above the representative range for that occupation. Therefore, while there had been a barrier to equal employment opportunity in the past, there is not one now due to affirmative actions practiced during the past three years. 
On the other hand, if the examination discloses that both the employment and accession rate for a particular group in a specific occupation are not within the representative range, and there are no other mitigating factors, then it would be reasonable to conclude that there is a potential problem or barrier requiring affirmative action. It would then be your responsibility to establish strong affirmative action objectives to identify and remove barriers. 
REASONABLE REPRESENTATION ANALYSIS

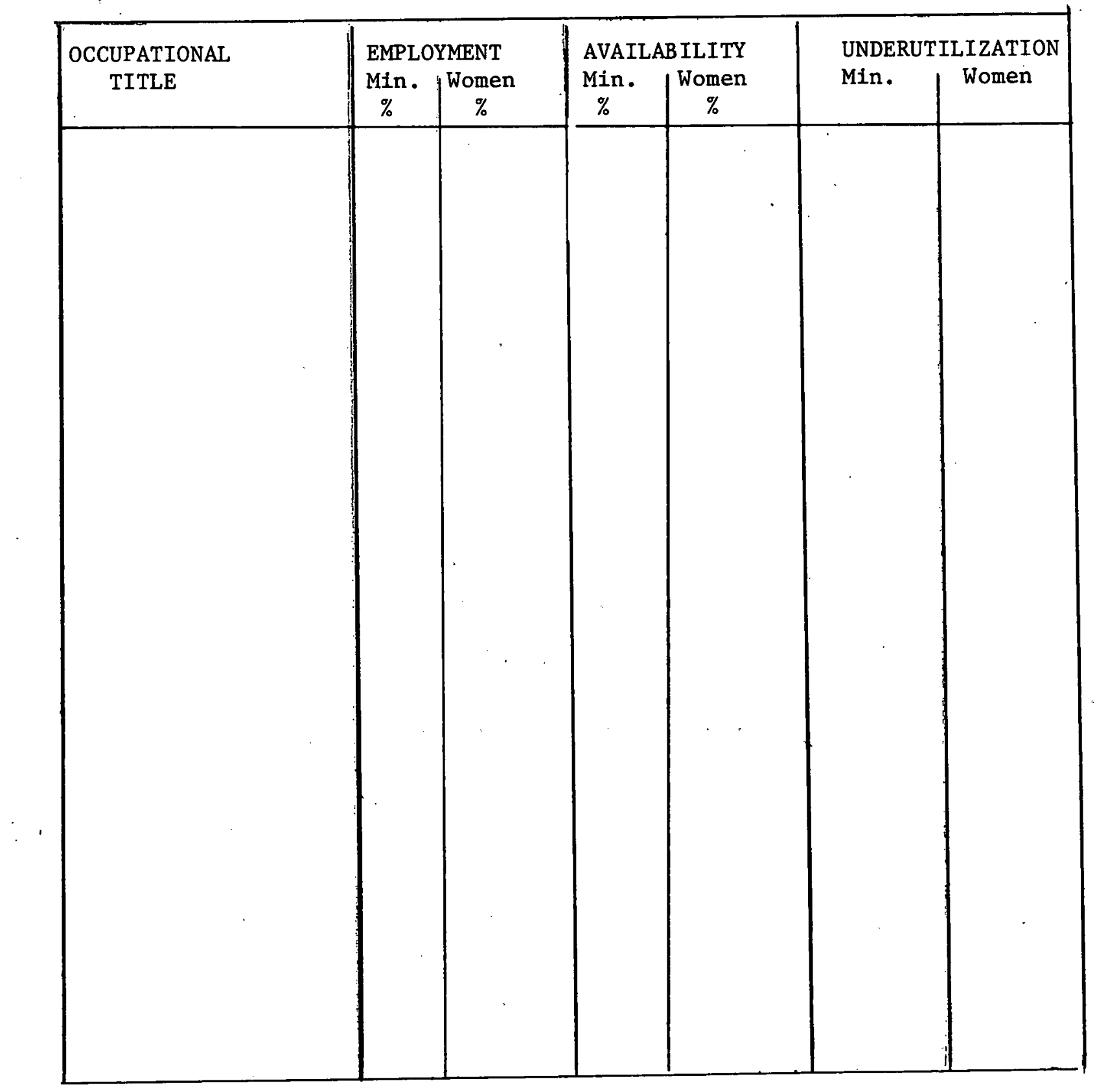

$-25-$ 


\section{SECTION 717 \\ PUBLIC LAW 92-261 \\ MARCH 24, 1972}

THE EQUAL EMPLOYMENT OPPORTUNITY ACT OF 1972 
Public Law 92-261

92nd Congress, H. R. 1746

March 24, 1972

\section{An Act}

To further promote equal emplojment opportunities for American workers.

$* * *$

\section{$\because$ NONDISCRIMINATION IN FEDERAI, GOVERNMENT EMPLOYMENT}

"SEc. 717. (a) All personnel actions affecting employees or applicants for employment (except with regard to aliens employed outsid the limits of the United States) in military departments as defined in section 102 of title 5, United States Code, in executive agencies (other than the General Accounting Office) as defined in section 105 of title 5 . United States Code (including employees and applicants for employment who are paid from nonappropriated funds), in the United States Postal Service and the Postal Rate Commission, in those units of the Goiernment of the District of Columbia having positions in the com: petitive service, and in those units of the legislative and judicial branches of the Federal Government having positions in the competitive service, and in the Library of Congress shall be made free from any discrimination based on race, color, religion, sex, or national origin.

"(b) Exrepht as otherwise provided in this subsection, the Civil Serv. ice Commission shall have authority lo en forco the provisions of subsection (a) through appropriate remedies, including reinstatement or hiring of employees with or without back pay, as will effectuate the policies of this section, and shall issue such rules, regulations, orders and instructions as it deems necessary and appropriate to carry out its responsibilities under this section. The Civil Service Commission shaill-

"(1) be responsible for the annual review and approval of a national and regional equal employment opportunity plan which each department and agency and each appropriate unit referred to in subsection (a) of this section shall submit in order to maintain an affirmative program of equal employment opportunity for all such employees and applicants for employment;
80 Stat. 378 .

Enforcement; rules and regulationo.

Natioral and regional plan, annual review. 
Progress reports, publication.

Librarian of Congress. authom ty.

42 USC 2000 note.

Ante, p. 104.

78 Stat. 259. 42 USC $2000 \mathrm{e}-$ 5.

USC prec. title 1.
"(2) be responsible for the review and evaluation of the operation of all agency equal employment opportunity programs, periodically obtaining and publishing (on at least a semiannual basis) progress reports from each such department, agency, or unit; and

"(3) consult with and solicit the recommendations of interested individuals, groups, and organizations relating to equal employment opportunity.

The head of each such department, agency, or unit shall comply with such rules, regulations, orders, and instructions which shall include a provision that an employee or applicant for employment shall be notified of any final action taken on any complaint of dissrimination filed by him thereunder. Tho plnin submitted by each department, agency, and unit shall include, but not be limited to-

"(1) provision for the establishment of training and education programs designed to provide a maximum opportunity for employees to advance so as to perform at their highest potential; and

"(2) a description of the qualificntions in terms of training and experience relating to equal rmploymont ojpurtunity. for the principul und operating officials of each such department, agency, or unit responsible for carrying out the equal employment opportunity program und of the allocation of personinel and resources proposed by such department, agency, or unit to carry out its equal employment opportunity program.

With respect to employment in the Library of Congrcss, authorities granted in this subseotion to the Civil Service Commission shall be exercised by the Librarian of Congress.

"(c) Within thirty days of receipt of notice of finnl action taken by a department, agency, or unit referred to in subsection 717 (a), or by the Civil Service Commission upon an appeal from a decision or order of such department, agency, or unit on a complaint of discrimination based on race, color, religion, sex or national origin, brought pursuant to subsection (a) of this section, Executive Order 11478 or any succeeding Executive orders, or after one hundred and eighty days from the filing of the initial charge with the department, agency, nr unit or with the Civil Service Commission on appenl from a decision or urder of such department, agrency, or unit until such time as final action may be taken by a department, agency, or unit, an employee or applicant for employment, if aggrieved by the final disposition of his complaint, or by the failure to take final action on his complaint, mny file a civil action as provided in section 706 , in which civil action the head of the department, agency, or unit, as appropriate, shall be the defendant.

"(d) The provisions of section 706 (f) through ( $k$ ), as applicable, shall govern civil actions brought hereunder.

"(e) Nothing contained in this Act shall relieve any Government agency or official of its or his primary responsibility to assure nondiscrimination in employment as required by the Constitution and statutes or of its or his responsibilities under Executive Order 11478 relating to equal employment opportunity in the Federal Government."

\footnotetext{
$* * *$
}

U. 5. GOVERNMENT PRRTING OFFICE : 19720 - 480-537 (132) 
CSC BULLETIN 713-50

FISCAL YEAR 1979 EQUAL EMPLOYMENT OPPORTUNITY PLANS 


\section{Bulletin}

Bulletin No. $713-50$

Washington, Ð. C. 20415

SUBJECT: Fiscal Year 1979 Equal Employment Opportunity Plans June 12, 1978

Action Date:

Heads of Departments and Independent Establishments:

1. This bulletin contains updated guidance for the preparation and submission of Fiscal Year 1979 equal employment opportunity plans. Agencies should comply with FPM Letter 713-40 except where changes are made by this bulletin.

2. The following special instructions apply to FY 1979 EEO plans:

a. Career Development for EEO Specialists. Agencies will report plans for implementing career development programs for EEO specialists in accordance with guidelines forwarded by Chairman Campbel1's nemurandum to heads of departments and agencies, dated January 11, 1978.

Agency plans, activities and accomplishments will be reported to the Civil Service Commission under the section in the EEO plan entitled, "Full Utilization of Skills and Training," and will include the following:

(1) A summary of the agency's analysis of the cross-training needs of personnel and EEO specialists;

(2) Actions underway or proposed to meet these needs;

(3) An assessment of how well specialists who have undergone training have increased their effectiveness; and

(4) A summary of any career progression of EEO sp cialists in personnel or other management fields.

Efforts undertaken during FY 1978 should be reported in Part B of the FY 1979 plan submitted to the Commission. All FY 1979 plans submitted to the Commission will be expected to include provisions for a comprehensive, continuing effort to implement this policy.

b. Submission of EEO plans. Agencies required to submit EEO plans for Civ1l Service Commission review should make every effort to forward approvable plans well in advance of the fiscal year so that Commission reviews may be completed as early as possible and agencies can begin the fiscal year with an approved plan. Plans received by August 1, 1978 will be given priority attention by Civil Service Commission offices and every effort will be made to complete the plan review process prior to the beginning of the fiscal year. In any case, however, FY 1979 plans must arrive at the appropriate Civil Service Comission office not later than October $1,1978$.

Inquiries: Office of Federal Equal Employment Opportunity, Affirmative Action/Upward Mobility Section, (202) 632-6256

Code: $\quad 713$, Equal Employment Opportunity

Distribution: FPM

Bulletin Expires: Apri1 20, 1979 
c. Agencies required to prepare and submit major subordinate organization plans are listed in the attachment to this Bulletin. Regional offices and local installations required to submit plans will be notified by the appropriate Civil Service Commission regional office.

d. Th1s report has been cleared in accordance with FPMR 101-11.11 and assigned interagency report control number 1046-CSC-AN,

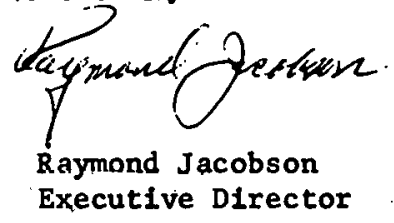


The following agencles are required to review, approve, and submit EEO plans for the organizations 11sted. Such plans will be forwarded to the Director, Office of Federal Equal Employment Opportunity, U. S. Civil Service Commission, with written affirmation that they meet the requirements of FPM Letter 713-40.

1. Department of Agriculture

- Parmers Home Administration

= Boreat Eervice

- Soil Conservation Service

- Agricultural Stabilization and Conservation Service

- Agricultural Marketing Service

- Food and Nutrition Service

- Agricultural Research Servi ce

- Animal Plant Health Inspection Service

- Federal Grain Inspection Service

- Food Safety and Quality Service

2. Department of Army

- U. S. Army Material Development and Readiness Camand

- U. S. Training and Doctrine Command

- U. S. Army Health Services Command

3. Department of Commerce

- National Bureau of Standards

- National Oceanic and Atmospheric Administration

- Patent and Trademark Office

- Bureau of the Census

4. Department of Health, Education, and Welfare

- Office of the Secretary

- Office of Human Development Services

- Public Health Service

- Health Care Financing Administration

- Social Security Administration

- Education Division

5. Department of Interior

- National Park Service.

- Geological Survey

- Bureau of Reclamation

- Bureau of Mines

- Bureau of Indian Affairs

6. Just1ce

- Pederal Bureau of Invest1gation

- Imalgration and Naturalization Service

- Bureau of Prisons

- Drug Enforcement Adninistration 
7. Department of Labor

- Employment and Training Adminiatration

- Employment Standards Administration

8. Department of Transportation

- U. S. Coast Guard

- Boderal Aviation Adninistration

- Pederal Highway Adninistration

9. Department of Treasury

- Internal Revenue Service

- U. S. Customs Service

- Bureau of Engraving and Printing

- Bureau of Alcohol, Tobacco and Firearms

- Bureau of the Mint

10. U. S. Postal Service

- Eastern Region

- Central Region

- Northeast Region

- Southern Region

- Western Region 
FPM LETTER 71.3-40

EQUAL EMPLOYMENT OPPORTUNITY PLANS 
United Slates Civil Service Commission

FPM Le:ter 713-40

\section{Federal Personnel Manual System}

FPM Lefter 713-40

SUBJECT: Equal Employment Opportunity Plans

Published in idvincis

ot incorperation in FPM

Chapter 713

RETAIN UNTR SUPERSEDED

Washington, D. C. 20415

August 17, 1977

FRM Letter $713-35$ is superseded

Heads of Depalftments and Independent Establishments

1. This letter transmits updated guidelines for the preparation of equal employment opportunity plans which are-submitted by Federal agencles to the Civil Service Comitssion for review and approval. The guidelines detalled in the attachment to this letter supersede those issued in FPM Letter 713-35, dated April 30, 1976.

2. The guidelines embody a number of changes - some suggested by agency officials - which are intended to improve the EEO planning process and substantially contribute to the attainment of EEO program objectives. Particular emphasis $1 \mathrm{~s}$ given to the requirement for each agency. to conduct a comprehensive assessment of its EEO status; to state concisely the EEO problems which exist in the agency; to establish measurable objectives which will solve those problems, and to list specific affirmative actions designed to meet EEO objectives. In addition, these guidelines stress the need for timely preparation of EEO plans and require that plans to be reviewed for approval. In accordance with P.L. 92-261 be submitted to the Civil, Service Commisston not. later than October 1 .

3. These guldelines become effective for plans developed for Flscal Year 1978.

4. This report has been cleared in accordance with FPMR 101-11.11 and assigned interagency report control number 1046-CSC-SA.

Attachnent

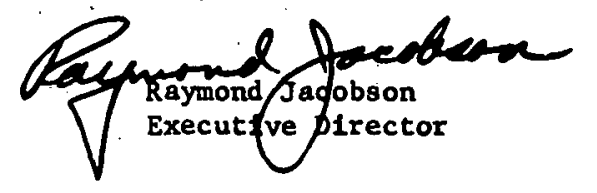

Inquiries: Office of Federal Equal Employment Opportunity, (202)632-6256, 632-6257

CSC Code: 713, Equal Employment Opportunity

Distribution. FPM (at:ance, edition limited) 
Attachment to FPM Ltr. 713- 40

Culdellan for the Development of Agency

Bqual Emplosmant Opportualey Plans 


\section{PREPARATION AND SUBMISSION OF EEO PLANS}

1. All plans will be developed on a fiscal year basis and become effective on the first day of the fiscal year.

2. Each department and agency identified in Section 717 (a) of P.L. 92-261 shall prepare a national equal cmployment opportunity plan. Such plans shall be submitted by the department or agency to the Director, Office of Federal Equal Employment Opportunity, U. S. Civil Service Commission, Washington D. C. 20415, not later than October 1 each year.

3. Major subordinate comanand organizations of the above departments and agencies shall prepare such plaus as the Commission shall. require. Such plans shall be reviewed and'submitted by the department or agency to the Director, OFEEO, not later than October 1 each year.

4. Regional offices and field installations of the above departments and agencies shall submit such EEO plans as the appropriate U. S. Civil Service Commission Regional Director, or for installations in the Washington D. C. metropolitan area the Director, OFEEO, shall require. Of these plans, those covering 1,000 or more employees shall be summitted by the head of the regional office or field installation directly to the appropriate U. S. Civil Service Commission office, not later than October 1 each year. A regional office or field instaliation preparing a plan which covers fewer than 1,000 employees will submit that plan for Commission review only upon the specific request of the Commission.

5. With one exception, organizations required to submit plans will develop them in accordance with instructions in this Letter. Excepted are small national agencies, generally those having fewer than 500 employees, and small local installations, generally those having fewer than 100 employees. These organizations are authorized to prepare modified EEO plans which will consist of the following elements:

a. Title page and Part A per these Guidelines.

b. Assurance that a current policy statement signed by the head of the agency which outlines the agency's commitinent to equal employment opportunity has been distriviled to alf enchloyces;

c. Assurance that all employees have been made aware of the discrimination complaint procedure, the name and location of the EEO counselor(s), and the name, title and location of the official with whom a formal discrimination complaint may be 5 : led; and

d. Assurance that there is a provision for the establishment ot training and education proyrams and upward mobility efforts designed to provide a maximis sportunity for employees to advance so as to perform at $t y: y$ highest potential. 
Such modified EEO plans shall. be submitted for Comission review only upon the request of the Conmission.

6. Agencies may develop and subrijt $\Gamma$ lans whose objectives and action items (Part D) extend beyond one fiscal year. The report of objectives and action items of national plans of agencies and major command organizations may not extend beyond four (4) years and regional plans beyond two (2) years. In each subsequent year, the agency will submit an Introduction; Accomplishment Report; Assessment.Report, and, if appropriate, an tupdaticu icport of objectives and Action Items. The updated Part $D$ will be requirer in ohow new, üudifled, or cerminated objectives or action items resulting from program changes within an agency, accomplishment or lack of accomplishment, or changes in results of assessment.

\section{PLAN DEVELOPMENT PROCESS - PROGRAM ASSESSMENT}

7. The first step in EEO plan development is to assess the current status of equal employment opportunity within the agency or installation. The person or staff responsible for preparing the plan must request and consider input from managers, supervisors the coordinators of the Spanish Speaking, Federal. Women's, and Upward Mobility Programs, plus any employee groups, labor organizations, minority and women's groups, and other parties:having a responsible interest in the agency's. EEO program.: Agencies must also draw upon the results of personnel management and EEO program evaluations conducted by the U. S. Civil Service Commission or agency internal evaluation units. EEO-related actions which an agency has been required to take in an offictal U. S. Civil Service Commission personnel management evaluation report must be addressed In the agency's EEO plan.

8. It is very important that the assissment proccss be inltlaced early enough to allow ample time for solicitation and consideration of input from all sources, and to assure that the plan is ready by Octoter 1 .

9. For program assessment and planning purposes the EEO program is divided into" eight major ateas of concern:

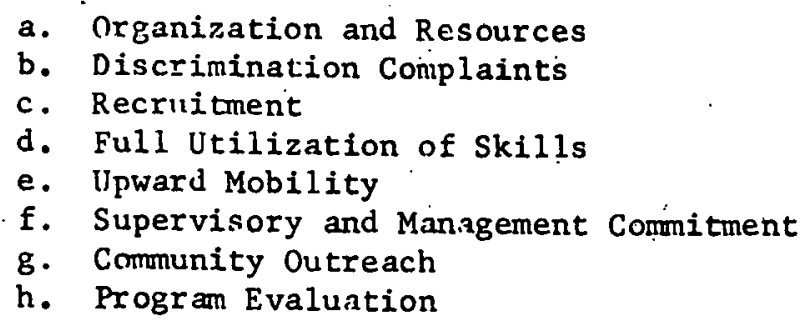

During the plan development process, agencies must evaluate the status of their EEO program in terms of these eight areas of concern. To assist ageñcies in this process, suggested criteria are presented in Appendix A for each of the eight areas. 


\section{CONTENT OF EEU PLANS}

10. EEO plans will be comprised of a title page, four major parts, and one attachment.

\section{a. Title Page (See Exhibit 1) \\ b. Part A - Introduction. This part must contain:}

(1) one copy of the official internal Personnel Manual Chapter on Equal Employment Opportunity to include the official policy statement on equal employment opportunity.

(2) statement explaining the delegated authorities, roles, and interrelationships of the EEO Director, EEO Officer, Coordinators of Federal Women's, Spanish Speaking, and Upward Mobility programs, Counselors, Investigators, Personnel officers, and EEO Comnittee members.

(3) a statement showing the extent of expected involvement in the EEO program of line and staff managers and supervisors, unions and othor employee groups, and employees.

(Statements required by 1,2 , and 3 , above, once submitted to the Civil Service Commission, may be referenced in subsequent plans. Any update or significant modifications should be submitted to the Commission.)

(4) a certification of qualifications of principal officials. (See Exhibit 2).

(5) a report of the personnel and resources which the agency plans to allocate to the program. (See Exhibit 3).

c. Part B - Accomplishment Report. This part must show:

(1) results achieved for each objective listed in the previous year's plan. (See Exhibit 4).

(2) a summary of discrimination complaint activity for the previous year. (See Exhibit 5).

(3) results of upward mobility program activities for the previous year. (See Exhibit 6).

NOTE: To avoid delays in the preparation and submission of EEO plans, accomplishments shown in Part $B$ may be reported as of the end of the third quarter, provided that a supplemental report of Parc B only, showing fourth quarcer accomplishments, is submitted to the appropriate Civil Service Commission of fice not later than January 1. 
d. Part C - Assessment Report. This part must contain:

(1) a summary of the assessment of each of the eight EEO areas of concern. Each summary will conclude with a brief statement of a specific problem or problems found as a result of the assessment. If no problem is identified within a particular area of concern, the words "no problems identified" should be stated.

(2) statistical data for each pay system used. (See Exhibits 7 and 8 ).

e. Part D - Report of Objectives and Affirmative Actions must containı (Ece Exhilut 4).

(1) clearly stated, specific, and measurable objectives and supporting action items which will solve problems identified in the assessment process.

(2) assignment of a responsible officlal for each objective and action item listed.

(3) a target dace for reaching each objective and action item.

f. As an attachment to the EEO plan, agencies and installations will include their Worker-Trainee Opportunities Plan. Guideilnes for participation in this program eligibility criteria for celling exemption, and formats for plan submission are contained in FPM Letter 713-33 dated Ootober 3, 1975.

\section{U. S. CIVIL SERVICE COMISSION REVIEW OF EEO PLANS}

11. P.L. 92-261 requires an annual review of agency EEO plans by the U. S. Civil Service Commission. The Commission's review is designed co assure that agency EEO plans are submitted on time, are complete In coverage, and are adequate in response to the assessment of EEO problems. Each plan will be substantively reviewed to determine whether It represents adequate efforts to assess the current status of equal employment opportunity within the agency and to deal reasonably with known problems or to bring about necessary improvements.

12. As a result of this substantive review, modification of agency plans will be required by the Commission on a finding that:

a. Problems or improvements needed and identifled by ef ther the agency or the Commission have not been addressed adequately or in a meaningful or reasonable manner; or

b. Numerical goals and timetables are established in a manner not consis tent with appropriate Comission regulations and guidance; or 
c. Goals and timetables are not included where circumstances clearly indicate that they would be appropriate and useful; or

d. Regional plans routinely follow national guidance and do not relate to local problems; or

e. Significant slippage has occurred in accomplishing objectives and/or action items and insufficient information is provided to demonstrate the nature and extent of efforts made.

13. When the Commission requires modifications of plans, agencies will be given a specified time period within which to respond.

The following pages contain criterla which each agency's EEO program should meet if it is to be vlable and results-orfented. Where agency EEO programs fall short of these criteria appropriate problem statements, objectives, and action items should be 1isted. While these criteria form a basis for the assessment (Part $c$ ), such an assessment need not - and seldom should - be imited to this particular list. The criteria listed here are intended to serve as a starting point for the assessment process and may well suggest other factors to be considered in plan ievel nmment. 


\section{Organization and Resources}

a. Criteria are established to measure the productivity and the cost-effectiveness of the EEO staff.

b. EEO staff officer or director has direct access to top management and lines of communication to agency supervisors.

c. EEO program officials have receivèd sufficient training In EEO, peroornel, administration, and management to deal knowledgeably with issues and problems within their areas of responsibility.

d. Adequate management and fiscal controls are established to track: all-resources devoted to the EED program.

e. EEO officials have adequate delegations of authority to prepare dispositions and resolve complaints of discrimination, and alternative delegations of authority are èstablished so that complaints: filed alleging discrimination within the EEO staff may be expeditiously handled.

f. The Federal Women's, Spanish Speaking, and Upward Mobility program coordinators devote sufficient time to accomplishing program objectives and EEO officials who have other principal assignmento. devote sufficient time to EEO program matters.

8. The Federal Women's, Spanish Speaking, and Upward Mob111ty program coordinators have adequate delegations of authority to promote. these programs and to accomplish program objectives.

h. EEO officials serve as technical advisors to the personnel office. 


\section{Discrimination Complaints}

a. Counselors are accessible to all employees at all locations.

b. All counselors have received training in personnel managenent and basic and advanced counseling.

c. The performance of counselors is perlodically evaluated,

d. Complaints are processed within 180 days.

o. The discrimination complaints process is periodically. reviewed to eliminate barriers.

f. All discrimination complaint Investigators have recelved tralning in personnel management and EEO.

8. Bases of complaints are analyzed and efforts made to prevent recurrence.

h. Regulations and supplemental guidance regarding class complaints have been distributed and explained. 


\section{Recruitment, ........}

a. Present recruitment sources yleld qualified minority and female applicants who meet organizational-needs.

b. Qualification requirements and procedures for hiring have been examined to determine whether barriers to EEO exist.

c. Recrultment literature reflects the agency's desire to reach all segments of the potential workforce:

d. EEO officials participate in the development of new-hires estimste report data.

e. Recruitment efforts are coordinated across organizational or, where appropriate, agency lines to obțain maximum effectiveness and efficiency:

f. EEO officials provide technical assistance to the personnel office and monitor (or participate in) recrultment efforts.

8. The interview and screening proces's is revlewed perlodically to ensure equal treatment regardless of race, color, religion, sex, national origin or age.

h. An analysis of relevant statistical data on the agency vorkforce is made perlodically to show:

(1) composition of the agency's and subordinate organizations' workforce by racial, ethnic and sex groupings at the various grade levels.

(2) composition of each major occupation (job series) by racial, ethnic, and sex groupings at the varlous grade levels. As supervisory position data become available, supervisory positions should be identified in each major occupation by grade.

(3) the number and kinds of jobs expected to be filled in the coming year based on a review of past turnover iates in each of the major occupations and anticipated expansion or contraction of programs.

(4) comparison of agency or installation occupational data with appropriate Federal civilian workforce data.

1. When pald advertising is used for recrultment or institutional purposes, coverage in minority media is included where appropriate. 
4. Rull Utilization of SkIlls and Training

a. A survey of current skills and training of the agency's workforce has been conducted to determine the availability of employees, including minorities and women, having skills required to meet agency staffing needs.

b. Information from the survey of skills is avallable for use in identifying underutilized employees. so they may be considered for positions which will make full use of their skills.

c. A system for updating a record of employee skills and training is in operation.

d. Studies have been conducted on time-in-grade to determine the reasons for any differentials which exist by minority status and sex.

e. Studies have been conducted to examine : relative upward movement of employees to full performance, professional, supervisory and highest grade levels.

f. Career counseling is avallable to all employees:

8. Efforts are being made to ensure that approprlate training opportunities are avallable to employees at all grade levels and in all occupational areas, without regard to minority $s$ tatus and sex.

h. Staffing plans take into account the need to assure meaningful career opportunities at all grade and pay levels for the on-board workforce.

1. Internal selection or promotion qualification requirements and procedures are valid and job-related, and include no innecessary barriers to full utilization of skills and training. 
5. Upward Mobility for Lower Level Employees

a. Upward mobility target jobs are systematically'identified to meet appropriate current and projected staffing needs.

b. Procedures are established to identify and advance underutilized employees.

c. Career counseling services are provided for all employees, including participants in UM programs.

d. Individual development plans are used. in the design of training which will help employees to qualify for. higher level jobs.

e. The Upward Mobility program is systematically monitored and evaluated.

f. EEO and Personnel officials, supervisors, and managers seek to improve and expand advancement opportunities for lower level employees.

8. The Upward Mobility program complies fully with program requirements published by $U$. S. Civil Service Commission on Upward Mobility.

6. Supervisory and Management Commitment

a. Al1 supervisory and management personnel have attended formal training which included coverage of their equal employment opportunity responsibilities.

b. The incentive awards system has been utilized to recognize supervisory and managerial personnel for their understanding and support of, and accomplishment in, equal employment opporturity.

c. Performance evaluations of supervisory and managerial personnel include a specific item or items evaluating understanding, support, and achievement of equal employment opportunity. 


\section{Community Outreach}

a. Management makes itself available to community, civic, and other groups interested in enhancing equal employment oppor tunities.

b. The agency, participates in cocperative efforts with Federal and other organizations to deal with employment. related problems in the community, including needs. for improved public transportation, education, and comminity services.

c. The agency provides opportunities and services to the community such as cooperative education programs and shared use of training facilities.

d. The agency participates in comminity career information programs; conferences, and occupational study projects.

e. The agency has examined means for expanding worker-trainee placements. Current plans call for maximim participation in the Vorker-Trainee Opportunities program with particular emphasis on the Identification of developmental positions. 


\section{Program Evaluation}

a. Findings from EEO program evaluations are incorporated into the required annual EFO plan development process.

b. EEO program evaluation is conducted by the EEO office, personnel office, internsl management audit office, joint effort of above offices or by some other organization. Lead and support responsibilities have been specified.

c. EEO Committees, where established, consult with the EEO officer, personnel office, and internal management. office to-ensure that each makes its contribution to EEO program. evaluation.

d. Statistical data necessary for EEO program evaluation are accurate, timely, and readily obtainabie.

e. The 'staff' responsible for conducting the EEO program evaluation is fully trained In EEO and merit system requirements as set forth in CSC. regulations and instructions.

f. EEO program evaluations include speciflc inputs frón Federal. Women's and Spanish Speaking Program coordinators.

8. Consultations with special emphasis progran coordinators polnt up issues worthy of follow-up.

h. Evaluations are scheduled so that their results are usefil in. EEO plan development. 


\section{(Title Page)}

Equal Employment Opportunity Plan

Fiscal Year

\begin{tabular}{lll}
\hline Name of Organization & $?$ & $\cdots$ \\
\hline Address of Organization
\end{tabular}

Address of Organization

Number of Employees Covered by this Plan

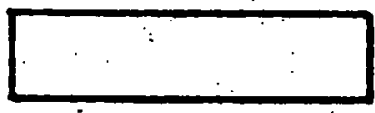

Name and Title of head of Organization

Signature

Date

th.

Name and Title of Principal EEO Official

Signature

Date

1046-CSC-SA 


\section{Certification of Qualificetions of Principal EEO Officials}

I certify that the qualifications of all staff officiais, full-time or part-time, concerned with administration of the EEO Program, including the Director of Equal Employment Opportunity: EF, Offlcer(s); Federal Women's Program Coordinator(s); and Spanish Speaking Program Coordinator (s) have been reviewed by competent authority and the incumbents of theoc positions meet the standards outlisied in Qualiflcations Standards Handbook X-118 under "Equal Opportunity Specialist GS-160" or "Qualifications Guide for Collateral Assignments Involving Equal Employment Opportunity Duties." Evidence: that the review has been made and its findings are on file and avallable for review by CIvil Service Coamission officials.

I further certify that the provisions of FPM Letter 713-37, Documenting EEO Collateral Duties in Officlal Position Descriptions, have been, or are In the procese of belug; met. 
Allocation of: Personnel and recsources for $\because:{ }^{\prime}$

\begin{tabular}{|c|c|c|c|c|}
\hline Program Areas & F' & PT & (a) $\%$ & Costs (b) \\
\hline EEO Program Admin. and Mgmt. & & & & \\
\hline a. EDO Director & & & & \\
\hline b. EEO Officer(s) & & & & \\
\hline c. Federal Women's Coordinator (s) & & & & \\
\hline -d. Spanish Speaking Coordinator (s) & & & & . \\
\hline e. Ujpward Mobility Coordinator(s) & & & & \\
\hline f. EEO Specialist(s) & & & & \\
\hline g. EEO Counselor (s) & & & & \\
\hline h. EEO Investigator(s) & & & & \\
\hline 1. Other Personnel & . & & & \\
\hline j. Other Administrative Expenses & & & & (c) \\
\hline TOTAL & & & & \\
\hline
\end{tabular}

a. Whell inore than one employee has the same responsibility in the program, l.e, counseling, do not show the percent of time spent.

b. For lines a through $i$ enter base salary plus $81 / 2 \%$.

c. Include al $\perp$ non-salary administrative expenses for EEO program such as travel, transcripts, reimbursement fees for EFO Investigators and EEO Complaints Examiners, and costs of training the above EEO officials. 


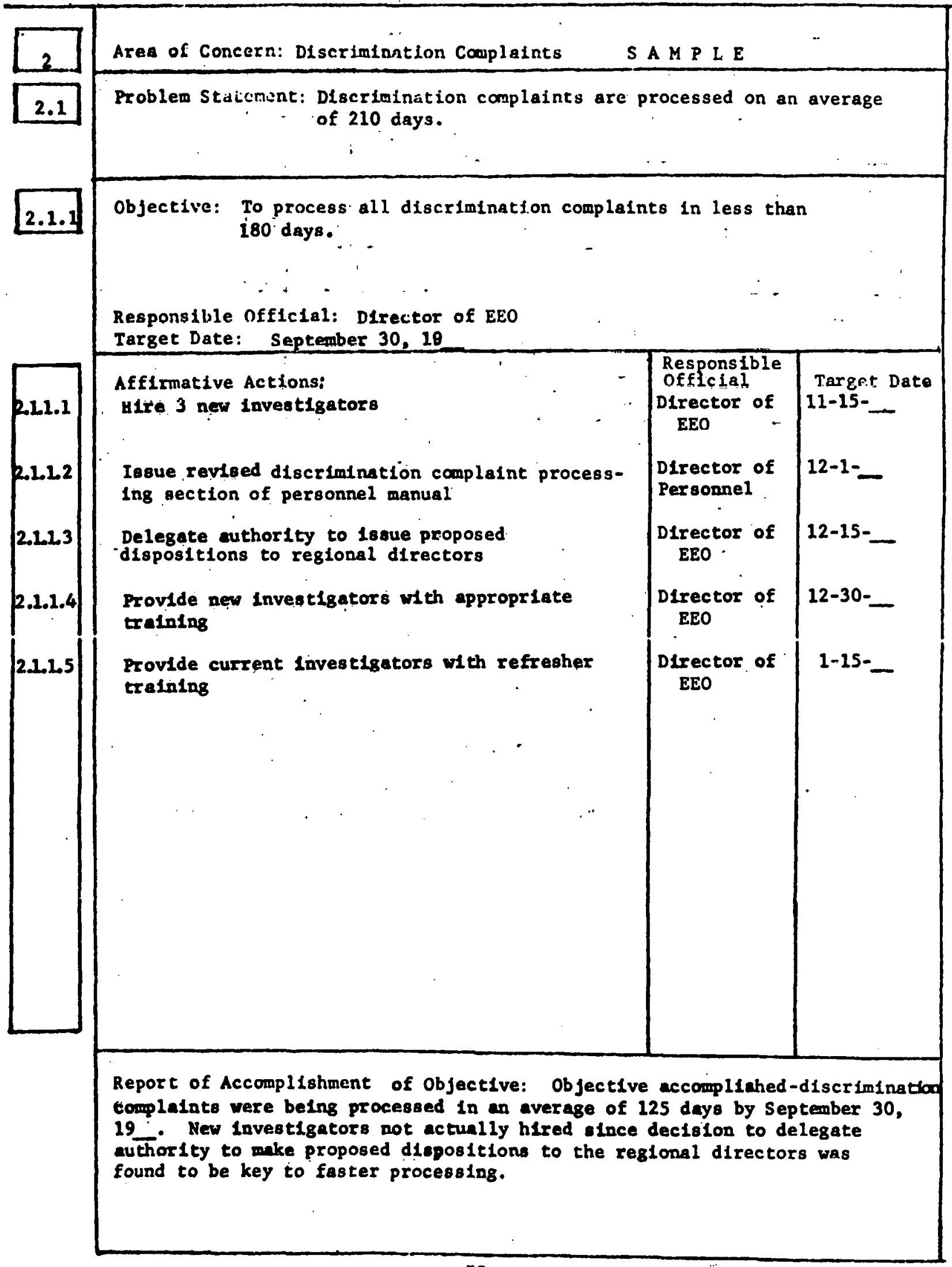




\section{Part B Accomplishment Report}

(Part B may show accomplishments through the third quarter of the fiscal year, in which case a supplemental report of Part B only, showing fourth quarter accomplishments will be submitted to the appropriate Civil Service Commission office not later than January 1.)

I. Show the extent of accomplishment of each nbjective listed in the previous year's plan. (See Exhibit 4 for format).

II. EEO Complaint Processing Summary

\begin{tabular}{|l|l|l|}
\hline Number of Complaints: & $\begin{array}{c}\text { Type of Complaint } \\
\text { Individual }\end{array}$ & Clags \\
\hline On hand at beginning of the year & & \\
\hline Received during the year & & \\
\hline Closed during the year & & \\
\hline On hand at end of the vear & & \\
\hline
\end{tabular}




\section{Upward jobility Progran Achievement}

A. Nunber of employees at and below GS-9 or equivalent who participated in at least three planned upward nobility program activities $I$ and who vere conpetitively

1. within the same orcupational series

2. LuLu a differèent occupational series

B. Nuibur of triloyees at and below GS-9 and enuivạlent tho participotcd in one or riore upward nohility propi:am activittes but sho vere neither promoted nnr reassigred.

C. Universe of potential Upward Moblilty Opportunities: Total number of position vacancies filled cumpetitively through merit principles below GS-10 and equivalent in all series and from all sources.

1/Upward Mub111ry Yecgxon Activic1es include: (1) assessment: oi an employ ie's kanwlctge, skills, abllities, and potential in relationship to the agency's 8 taffing neers; (2) counselirg to assist employees in the identification and achlevement of carecr goals; (3) foritulation of an Individual. training plan for on employee which contains the sequence, types, sources, dates, and cost of the training and experience required for that employee to qualify for. an identified target ponition or for a longer-range occupational goal; and (4) on-the-fob and/or forral classroom training as prescribrd by the training ylan.

2/ Target positions are spectif.cally identificd positions having knowra advancement fotential. 
PERCENTAGE DISTR IBUTION OF MTNCRITY/SEX GROUPS

FULL-TIME GENERAL SCHEDULE EMPLOYNENT AS OF ( DATE )

\begin{tabular}{|c|c|c|c|c|c|c|c|c|c|c|c|c|c|c|}
\hline \multirow{2}{*}{\multicolumn{2}{|c|}{$\begin{array}{l}\text { GENERAL } \\
\text { SCHEDULE } \\
\text { GRADE } \\
\end{array}$}} & \multirow{2}{*}{$\begin{array}{l}\text { NUMBER } \\
\text { EMPEOYEES }\end{array}$} & \multicolumn{2}{|c|}{$\%$ TOTAL } & \multicolumn{2}{|c|}{$\%$ BLACKS } & \multicolumn{2}{|c|}{$\%$ HIS PANICS } & \multicolumn{2}{|c|}{ \%AMER ICAN INDIANS } & \multicolumn{2}{|c|}{$\%$ ORIENTALS } & \multicolumn{2}{|c|}{$\%$ OTHER } \\
\hline & & & TOTAL & WOMEN & TOTAL & WOMEN & TOTAL & WOMEN & TOTAL & WOMEN & TOTAL & WOMEN & TOTAL & WOMEA \\
\hline & GS-1 & & $i \mathrm{CO}$ & & & & & & & & & 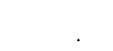 & & \\
\hline & GS -2 & & 200 & & & & & & & & & & & \\
\hline & GS -3 & & 100 & & & & & & . & & & & & \\
\hline & $\operatorname{cs}-4$ & & 100 & & & & & & & & & & & \\
\hline & GS-5 & & 100 & & & & & & & & & & & \\
\hline & GS -6 & & 100 & & & & & & & & & & & \\
\hline & GS-7 & & 100 & & & & & & & & & & & \\
\hline 1 & GS-8 & & .100 & & & & & & & & & & & \\
\hline G & GS-9 & & 100 & & & & & & & & $\therefore$ & & & \\
\hline 1 & & r. & & & & & & & & & & & & \\
\hline & GS +10 & & 100 & & & & & & & & & & & \\
\hline & Gs-11 & & 100 & & & & & & & & & & & \\
\hline & $G s-12$ & & 100 & & & & & & & & & & & \\
\hline & GS-13 & & 100 & & & & & & & & & & & \\
\hline & $C S-14$ & . & 100 & & & & & & & & & & & \\
\hline 8 & GS-15 & . & 100 & 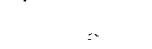 & & & & & & & & & & \\
\hline 8 & GS-16 & & 100 & & & & & & & . & & & & \\
\hline$\checkmark$ & GS-17 & & 100 & & & & & & & & & & & \\
\hline & GS-18 & & 100 & & & & & & & & & & & \\
\hline
\end{tabular}


PERCENTAGE DISTRIBUTION OF MINORITY/SEX GROUPS TWENTY MOST POPULOUS OCCUPATIOAAL SER IES

AS OP ( DATE )

SERIES

AND

JOB TITLE

NUBBER

EMPLOYEES
$\%$ TITAL

TOTAL WOMI

\begin{abstract}
$\%$ BLACES
\end{abstract}
TOTAL WOME
\% HISPANICS

TOTAL HOMBI
\% AMgR. IND. \% OR IENTALS

TOTAL WOMEN TOTAL WOMEN
$\%$ OTHER

TOTAL WOMEN

1

ส

1 
United States

Department of Energy

Washington, DC 20545

Official Business

Penalty for Private Use, $\$ 300$

Postage and Fees Paid

U.S. Department of Energy

DOE-350

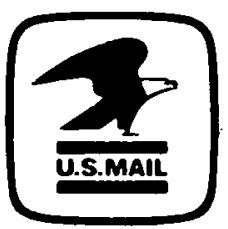

